\title{
SOFTWARE FOR THE DESIGN OF GEARING WITH AN ASYMMETRIC PROFILE
}

\section{ONDŘEJ MILÁČEK}

CTU in Prague, Department of Automotive, Combustion Engine and Railway Engineering, Vehicle Center of Sustainable Mobility, ondrej.milacek@fs.cvut.cz

\section{ABSTRACT}

This article is a continuation of previously published articles. This paper briefly describes the positive and negative qualities of asymmetric gearing from the point of view of loading conditions applied at the gearset, and the development and latest update of the software for designing this special involute gearing. The precise profile of the manufacturing tool is also described. All display options, and the option of gear mesh animation using this program, is shown. All equations necessary for the gearing geometry description, and a special approach with respect to $\mathrm{x}$-shift coefficients distribution, are also mentioned in this paper.

KEYWORDS: ASYMMETRIC, INVOLUTE, GEARING, EXTERNAL, ANIMATION, TIP CHAMFER, PROTUBERANCE, RACK

\section{SHRNUTí}

Tento článek je pokračováním dřive publikovaných článků. Stručně popisuje pozitivní a negativní vlastnosti asymetrického ozubení z pohledu zátěžných stavů působících na ozubené soukolí, a vývoj a poslední změny nového softwaru určeného pro návrh tohoto speciálního evolventního ozubení. Detailní profil výrobního nástroje je rovněž zmíněn. Prezentovány jsou všechny možnosti zobrazení a možnosti nastavení animace záběru ozubení, které tento program umožňuje. Zmíněny jsou také veškeré rovnice, popisujicí geometrii ozubení a zvláštní přistup $\mathrm{k}$ rozdělení koeficientů jednotkového posunutí x.

KLÍČOVÁ SLOVA: ASYMETRICKÉ OZUBENÍ, INVOLUTA, OZUBENII, VNĚJŠİ, ANIMACE, SRAŽENÍ HRANY NA HLAVĔ ZUBU, PROTUBERANCE, VÝROBNÍ HŘEBEN

\section{INTRODUCTION}

The issue of involute gearing geometry is a topic well-covered by specialist literature. It is very important to connect the influence of the production technology. Modern technologies allow the fine-tuning of the profile using CNC milling, electrical discharge machining (EDM) or grinding machines. In this article, the gearing profile is created purely by a trochoidal milling method with a cutting tool (rack). This rack profile also includes the tip chamfer and the protuberance. The gearing profile can be asymmetric.

\section{NOMENCLATURE AND USAGE OF ASYMMETRIC GEARING}

Initially, the side (flank) nomenclature should be defined. When driving a car, the power is transmitted at the "drive" flank; with engine (ICE) braking (going downhill without the gas pedal pressed), power is transmitted from the wheels to the engine via the "coast" flank of the teeth. In the case of a passenger car, load conditions at both tooth flanks can be very different. This important difference is caused by ICE turbocharging (torque increase). This means that one tooth flank is used much more often and with higher loading torque than the opposite one. This situation is depicted in Figure 1. The recorded torque during a real test drive of a passenger car is used as input data. These measured torque values are then sorted into "load levels". At each load level is then calculated an average torque and number of occurrences - the "load level spectrum". The effect of this whole loading spectrum on the gearset can then be transformed into loading with constant "equivalent" torque $\mathrm{M}_{e}$, which causes the same damage as the spectrum while undergoing the same number of cycles $\mathrm{n}$. The exact procedure of its processing is described in [1].

Figure 1 depicts a typical situation for a passenger car where the tooth flank at the coast side is loaded only with the torque value of $49 \%$ and only for $35 \%$ of loading cycles in comparison with the drive flank. In the case of lorries, loading torque at the coast 
side increases due to usage of an engine brake or retarder, so there are comparable loading conditions at both flanks. For this reason, a symmetric gearing profile makes sense is in this case.

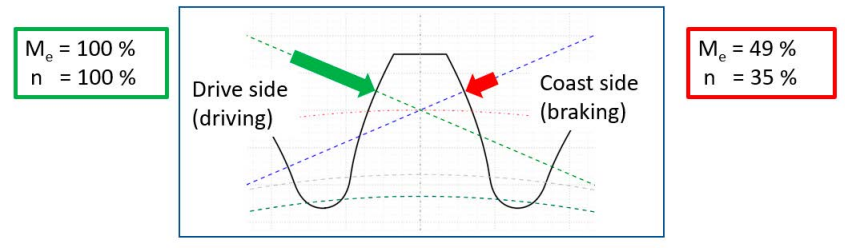

FIGURE 1: Loading conditions of the passenger car at both tooth flanks while driving and braking by ICE.

OBRÁZEK 1: Zátěžné stavy v osobním vozidle na obou stranách zubu, pohon a brzdění motorem

From the point of view of gearing durability, a symmetric profile in the case of passenger cars is not ideal. One side is always either overloaded or has excessive durability, particularly from the perspective of Hertzian (contact) stresses, which affect pitting formation. To optimize the durability at both tooth sides according to loading conditions, it is useful to reduce the contact stress on the drive side. This reduction can be achieved using an asymmetric gearing profile. This means that the most important parameter of the rack profile - angle $\alpha_{n}\left(\alpha_{P 0}\right)$ - is not same for both sides.

\section{RELIABILITY COMPUTATION}

\section{METHODOLOGY FOR ASYMMETRIC}

\section{GEARING}

Analytically, the Hertzian stress at a single tooth contact can be computed using a formula (1), where both osculation radii of touching bodies are known. In the case of a helical gearset, these bodies are cylinders with radii $\rho_{1,2}$.

$$
\sigma_{H}=\sqrt{\frac{F_{n}}{\pi \cdot b} \cdot \frac{E}{2 \cdot\left(1-v^{2}\right)} \cdot\left(\frac{1}{\rho_{1}}+\frac{1}{\rho_{2}}\right)}
$$

$\begin{array}{lll}\text { where: } & \sigma_{\mathrm{H}} & \text { Hertzian stress } \\ \mathrm{F}_{\mathrm{n}} & \text { normal force } \\ \mathrm{b} & \text { facewidth } \\ \mathrm{E} & \text { Young's modulus of elasticity } \\ v & \text { Poisson's ratio } \\ \rho_{1,2} & \text { osculation radii }\end{array}$

For involute gearing, the values of these osculation radii are dependent on its geometry. The situation is depicted in Figure 2.
This figure shows that these values are given, based on the involute geometry, as

$\rho_{1,2}=r_{w 1,2} \cdot \sin \alpha_{t w}$

where: $\rho_{\mathrm{w} 1,2} \quad$ working pitch radii of both gearwheels $\alpha_{\mathrm{tw}} \quad$ working transverse pressure angle

This means that the contact stress can be reduced while maintaining the gearset's major dimensions only by increasing the working transverse pressure angle $\alpha_{\mathrm{tw}}$. It is also clear that these osculation radii are much bigger at the drive side (blue) than at the coast side (green).

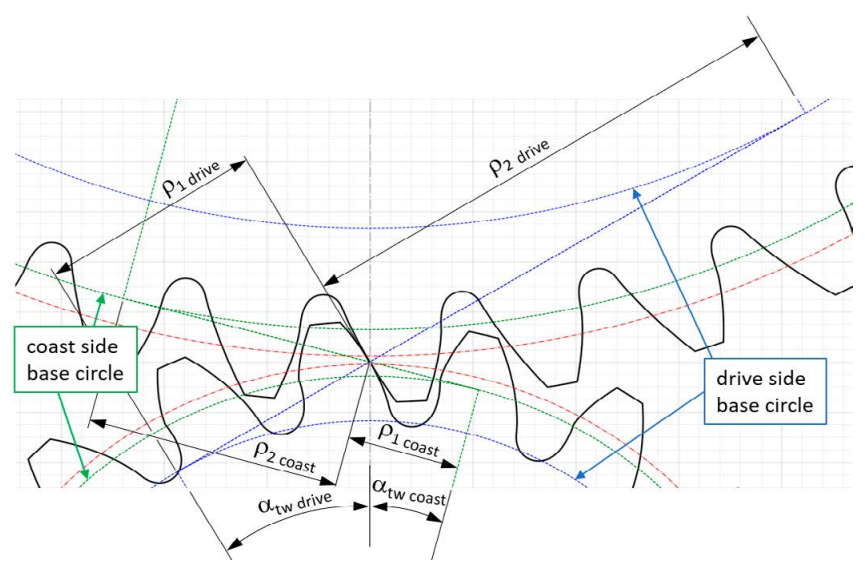

FIGURE 2: Osculation radii of involute gearset for single tooth contact in the mesh point.

OBRÁzEK 2: Oskulační poloměry (poloměry křivosti) evolventního ozubení při jednopárovém záběru ve valivém bodě.

Unlike for symmetric gearing, no standards yet exist for calculation of the lifetime of involute gearing with an asymmetric profile. For this reason, FEM simulation must be used firstly for symmetric gearing. These results must be compared with the stress obtained from a standardized calculation. Included in this calculation are all meshing and loading conditions using necessary coefficients (e.g. software KissSoft). By comparing both these results, recalculation coefficients are defined - see formula (3) for contact stress and formula (4) for root bending stress at each gearwheel.

$$
\begin{aligned}
& k_{H_{F E M}}=\frac{\sigma_{H_{\text {KissSoft }}}}{\sigma_{H_{F E M}}} \\
& k_{F E M_{1,2}}=\frac{\sigma_{F_{\text {KissSoft }}, 2}}{\sigma_{F E M_{\text {drive side }}, 2}}
\end{aligned}
$$

These coefficients are then used for backward recalculation of FEM results of asymmetric gearing to be comparable with 


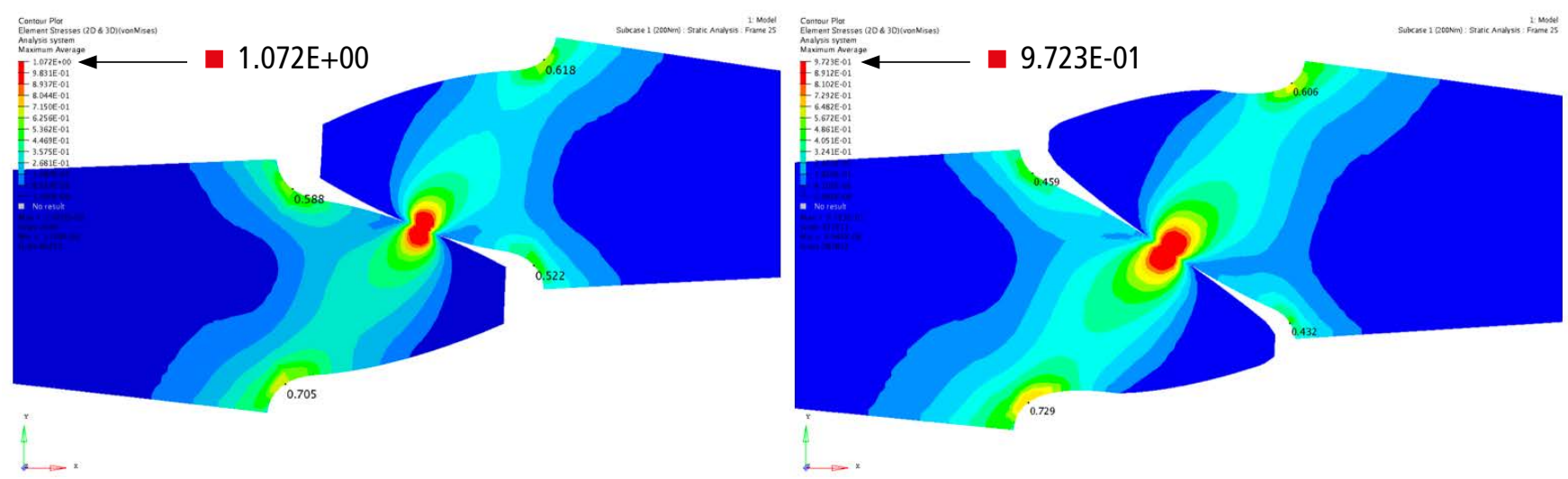

FIGURE 3: Example of FEM analysis of symmetric and asymmetric gearing, both profiles were designed using developed program. OBRÁzEK 3: Př́ílad FEM analýzy symetrického a asymetrického ozubení, oba profily byly vytvořeny s pomocí popisovaného programu

symmetric gearing results. To obtain the asymmetric gearing profile as an input for FEM analysis, the software described in the following chapter was developed.

The output from this program is also very important. The final gearset design from this program is further used for the creation of a 3D CAD model (e.g. to Catia using a function "Design Table") to create an input file (*.stp or *.igs) for an FEM solver. To be able to transfer the geometry further there is an option of saving all necessary parameters and coordinates of all calculated points into a "*.csv" file. An important advantage of this program is that the output is a chosen amount of calculated points, so the change of the design in 3D is then very fast - just the loading of a new (rewritten) design table in MS Excel.

The following Figure 3 depicts an example of gearset FEM analysis. It's a comparison of symmetric and asymmetric variants of a gearset. The decrease in the contact pressure by the same load (torque) for the asymmetric variant is approx. 9.3\%. Values of maximum stress (von Mises [GPa]) are enlarged to be readable. On the other hand, asymmetric profile (higher pressure angle) also has one negative consequence - the increase in radial forces, which cause higher loading on the bearings.

\section{STANDARD APPROACH TO SYMMETRIC INVOLUTE GEARING DESIGN}

When designing the macrogeometry of a symmetric gearset according to applicable standards (e.g. DIN 3990:1987, Method $B$ in KissSoft), all input parameters must be determined. In the next step, the sum of required $x$-shift coefficients $x_{\Sigma}$ for the gearset can be calculated using equation (5).

$x_{\Sigma}=x_{1}+x_{2}=\frac{z_{1}+z_{2}}{2 \cdot \operatorname{tg} \alpha_{n}} \cdot\left(\operatorname{inv} \alpha_{t w}-i n v \alpha_{t}\right)$ where: $\mathrm{x}_{1,2} \quad \mathrm{x}$-shift coefficients

$\mathrm{z}_{1,2} \quad$ number of teeth

$\alpha_{\mathrm{n}}\left(\alpha_{\mathrm{P} 0}\right)$ normal (tool) pressure angle

$\alpha_{t} \quad$ transverse pressure angle

$\alpha_{\mathrm{tw}} \quad$ working transverse pressure angle

This value of $x_{\Sigma}$ is calculated with the condition of no backlash, and is then divided among each gearwheel according to loading or geometrical conditions and demands on the wheels. Finally, needed backlash is implemented to the final gear shape by the given standard (e.g. DIN 3967). An example of such gearing including the backlash can be seen in Figure 4.

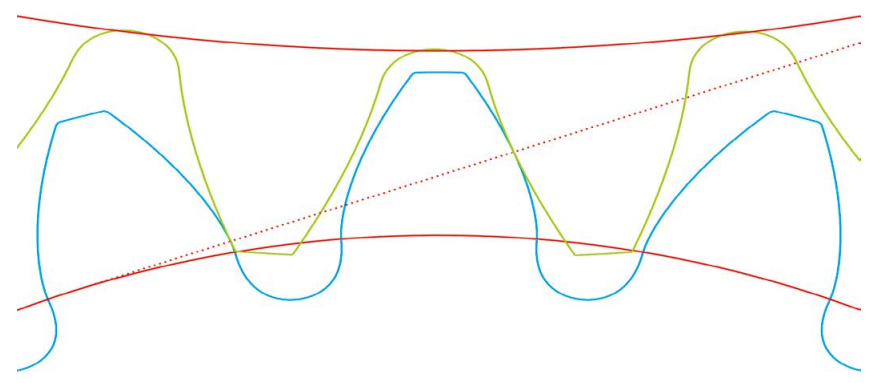

FIGURE 4: Example of the gearset appearance including the backlash designed in KissSoft

OBRÁzEK 4: Ukázka vzhledu ozubeného soukolí (včetně vůle), navrženého v programu KissSoft

\section{ASYMMETRIC INVOLUTE GEARING GEOMETRY DESCRIPTION}

In the case of a symmetric profile (rack), the tooth thickness is simply divided into two identical halves. In the case of asymmetric gearing, the situation is different. Figure 5 shows 
the situation in the transverse plane during manufacture, i.e. the mesh of the tool (rack) with a gearwheel. All values with the symbol " 0 " are related to a tool. The tool geometry description follows. A basic parameter is the thickness at tool reference plane $s_{t 0}$, which equals half of the transverse pitch $p_{t 0}$, as in the case of a symmetric version.

$s_{t 0}=\frac{p_{t 0}}{2}=\frac{\pi \cdot m_{t}}{2}$

where: $m_{t} \quad$ transverse module

This tool thickness is a sum of partial tool thicknesses at both sides (drive and coast)

$s_{t 0}=s_{t 0 \text { drive }}+s_{t 0 \text { coast }}$

Furthermore, the asymmetry ratio " $A$ " depending on the transverse profile angles can be defined as the ratio of both these thicknesses

$A=\frac{s_{\text {to drive }}}{s_{\text {to coast }}}=\frac{\tan \alpha_{t \text { drive }}}{\tan \alpha_{\text {t coast }}}$

For symmetric gearing this value is $A=1$. For asymmetric gearing there is standardly higher value of the profile angle $\alpha_{t}$ on the drive side. From this reason also the thickness on the drive side is higher than on the coast side and thus the asymmetry ratio is standardly $A>1$.

$s_{\text {t0 drive }}=s_{t 0} \cdot \frac{A}{1+A} \quad, \quad s_{t 0 \text { coast }}=s_{t 0} \cdot \frac{1}{1+A}$

Regarding the tooth profile, the rack shift must be considered. If the $x$-shift coefficient is equal to zero, the tooth thickness $s_{t}$ at the reference diameter $d$ is the same as the thickness of the tool (gap) $s_{t 0}$. If the rack is in a general position, i.e. shifted about the distance of " $x . m_{n}$ " as depicted in Figure 5, tooth thicknesses at reference diameter on both sides are still divided in same ratio $A$ and their values are

$$
\begin{aligned}
& s_{\text {t drive }}=s_{t 0 \text { drive }}+x \cdot m_{n} \cdot \tan \alpha_{t \text { drive }}= \\
& =s_{t 0 \text { drive }}+x \cdot m_{t} \cdot \tan \alpha_{n \text { drive }}
\end{aligned}
$$

and

$$
\begin{aligned}
& s_{t \text { coast }}=s_{t 0 \text { coast }}+x \cdot m_{n} \cdot \tan \alpha_{t \text { coast }}= \\
& =s_{t 0 \text { coast }}+x \cdot m_{t} \cdot \tan \alpha_{n \text { coast }}
\end{aligned}
$$

where: $m_{n} \quad$ normal module $\beta \quad$ helix angle

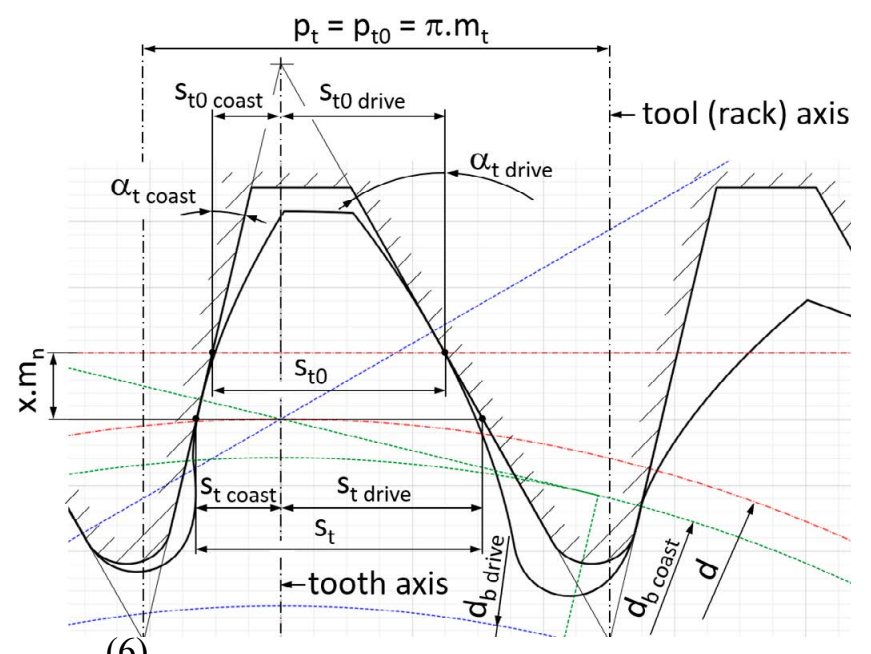

FIGURE 5: Situation in transverse plane while manufacturing of asymmetric gearing

OBRÁZEK 5: Situace v tečné rovině při výrobě asymetrického ozubení

To be able to derive a formula for a needed sum of $x$-shift profile coefficients for the case of asymmetric gearing without a backlash, the basic condition of correct mesh must be used, see formula (12). The meaning is that the sum of tooth thicknesses of mating gears at their working pitch diameters must remain the transverse pitch.

$p_{t w}=s_{t w 1}+s_{t w 2}$

These working pitch diameters can be calculated purely from the kinematic ratio using of number of teeth as (13)

$r_{w 1}=\frac{a_{w}}{1+\frac{z_{2}}{z_{1}}} \quad, \quad r_{w 2}=\frac{a_{w} \cdot \frac{z_{2}}{z_{1}}}{1+\frac{z_{2}}{z_{1}}}$

For a symmetric gearing, these thicknesses $s_{t w 1,2}$ can be computed using formula (14) as

$s_{t w 1,2}=d_{w 1,2}\left(\frac{s_{t 1,2}}{d_{1,2}}+i n v \alpha_{t}-i n v \alpha_{t w}\right)$,

inv $\alpha=\tan \alpha-\alpha[\mathrm{rad}]$

where working transverse pressure angle $\alpha_{t w}$ can be calculated using formula (15) as

$$
\alpha_{t w}=\arccos \left(\frac{a_{n}}{a_{w}} \cdot \cos \alpha_{t}\right)
$$

where: $a_{n}=r_{1}+r_{2} \quad$ nominal center distance $a_{w}=r_{w 1}+r_{w 2} \quad$ working (real) center distance 
For an asymmetric profile, these thicknesses $s_{t w 1,2}$ can also be computed, using formula (14), but separate for each tooth side.

Radii must be used instead of diameters, see formulas (16) and (17).

$s_{t w \text { drive } 1,2}=r_{w 1,2}\left(\frac{s_{t \text { drive } 1,2}}{r_{1,2}}+i n v \alpha_{t \text { drive }}-i n v \alpha_{t w \text { drive }}\right)$
$s_{t w \text { coast } 1,2}=r_{w 1,2}\left(\frac{s_{t \text { coast } 1,2}}{r_{1,2}}+i n v \alpha_{t \text { coast }}-i n v \alpha_{t w \text { coast }}\right)$

By the summing of these two parts, total tooth thickness can be defined on working pitch diameters $d_{w 1,2}$ for both gearwheels, see formula (18)

$s_{t w 1,2}=s_{t w}$ drive $1,2+s_{t w}$ coast 1,2

The aim is to determine needed sum of both $\mathrm{x}$-shift coefficients. From this reason these values $x_{1,2}$ must be used for description of the thicknesses $s_{t w 1,2}$, see equation (19).

$$
\begin{aligned}
s_{t w 1,2}=r_{w 1,2} & \left(\frac{m_{t} \cdot \pi}{2 \cdot r_{1,2}}+\frac{m_{t} \cdot x_{1,2}}{r_{1,2}} \cdot\left(\tan \alpha_{n \text { drive }}+\tan \alpha_{n \text { coast }}\right)+i n v \alpha_{t \text { drive }}\right. \\
& \left.-i n v \alpha_{t w \text { drive }}+i n v \alpha_{t \text { coast }}-i n v \alpha_{t w \text { coast }}\right)
\end{aligned}
$$

The sum of these two thicknesses follows, see formula (20).

$$
\begin{aligned}
& s_{t w 1}+s_{t w 2}=\frac{m_{t} \cdot \pi}{2} \cdot\left(\frac{r_{w 1}}{r_{1}}+\frac{r_{w 2}}{r_{2}}\right)+\left(x_{1}+x_{2}\right) \cdot m_{t} \cdot \frac{r_{w 1}}{r_{1}} \cdot\left(\tan \left(\alpha_{n \text { drive }}\right)+\tan \left(\alpha_{n \text { coast }}\right)\right)+\left(r_{w 1}+r_{w 2}\right) \\
& \cdot\left(i n v \alpha_{t \text { drive }}-i n v \alpha_{t w \text { drive }}+i n v \alpha_{t \text { coast }}-i n v \alpha_{t w \text { coast }}\right)
\end{aligned}
$$

The value of $\left(r_{1}+r_{2}\right)$ can be substituted using formula (21). Values of appropriate mesh angles $\alpha_{t}$ and $\alpha_{t w}$ can be taken either from drive or coast side because their ratio used in formula (21) remains same for both of them.

$$
r_{w 1}+r_{w 2}=a_{w}=a_{n} \cdot \frac{\cos \alpha_{t \text { drive }}}{\cos \alpha_{t w \text { drive }}}=\frac{\left(z_{1}+z_{2}\right) \cdot m_{t}}{2} \cdot \frac{\cos \alpha_{t \text { drive }}}{\cos \alpha_{t w \text { drive }}}
$$

Transverse pitch $p_{t w}$ at working pitch diameters $d_{w 1,2}$ can be computed using formula (22) as

$$
p_{t w}=p_{t} \cdot \frac{d_{w}}{d}=\pi \cdot m_{t} \cdot \frac{d_{w}}{d}=\pi \cdot m_{t} \cdot \frac{\cos \alpha_{t \text { drive }}}{\cos \alpha_{t w \text { drive }}}=\pi \cdot m_{t} \cdot \frac{\cos \alpha_{t \text { coast }}}{\cos \alpha_{t w \text { coast }}}
$$

Now it is possible to put all needed formulas into the equation (12). The final result of this condition is the desired sum of $x$-shift coefficients $x_{1}+x_{2}$ of both gearwheels, see formula (23).

$x_{\Sigma}=x_{1}+x_{2}=\frac{\left(z_{1}+z_{2}\right) \cdot\left(i n v \alpha_{t w d r i v e}-i n v \alpha_{t d r i v e}+i n v \alpha_{t w \text { coast }}-i n v \alpha_{t \text { coast }}\right)}{2 \cdot\left(\tan \alpha_{n \text { drive }}+\tan \alpha_{n \text { coast }}\right)}$ 
As it was already mentioned, value of $x_{\Sigma}$ resulting from the equation (23) is derived for the condition of theoretical mesh with no backlash between tooth flanks. Similarity with the equation (5) is obvious at the first glance. The only difference lays in the fact, that appropriate expressions are used separately for each tooth side, instead of one value identical on both sides as for symmetric profile. One of these two values $x_{1,2}$ must be set and the second one is then calculated from $x_{\Sigma}$.

\section{DEPICTION OF THE GEARSET INCLUDING THE BACKLASH}

For assuring of correct gearset function some minimal backlash is needed between tooth flanks while meshing. To be able to determine and depict this circumferential transverse backlash $j_{t}$ we must focus again on working pitch diameters $d_{w 1,2}$ where thicknesses of mating gears are important. On these diameters transverse working pitch $p_{t w}$ remains same as for the case of meshing without a backlash and can be defined using formula (22). Teeth thicknesses of both gears can be computed using formula (19). Fundamental condition for meshing without a backlash expressed by the equation (12) then changes to the equation (24), where circumferential backlash $j_{t}$ is already considered.

$p_{t w}=s_{t w 1}+s_{t w 2}+j_{t}$

Formula (24) can then be used to express the circumferential transverse backlash $j_{t}$ as

$j_{t}=p_{t w}-s_{t w 1}-s_{t w 2}$

From this formula (25) it is clear, that the sum of both tooth thicknesses $s_{t w 1,2}$ must be smaller than for the case without clearance. These thicknesses are influenced by the values of $x$-shift coefficients. This means that for case including the backlash the equation (23) cannot be used. When considering a real case including the backlash, both values of $x_{1,2}$ must be entered and resulting transverse backlash $j_{t}$ can be then calculated.

More important than circumferential transverse backlash $j_{t}$ is the normal one $j_{n}$. In the case of asymmetric gearing, the same formula is used as for a symmetric profile, but relevant angles differ at both sides, see formula (26).

$$
\begin{aligned}
& j_{n \text { drive }}=j_{t} \cdot \cos \alpha_{t w \text { drive }} \cdot \cos \beta_{w} \\
& j_{n \text { coast }}=j_{t} \cdot \cos \alpha_{t w \text { coast }} \cdot \cos \beta_{w}
\end{aligned}
$$

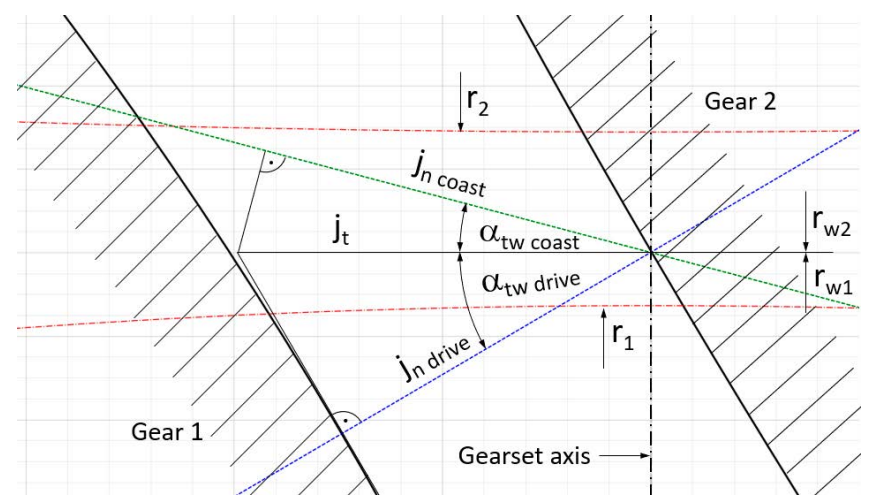

FIGURE 6: Recalculation from circumferential transverse backlash to normal backlash - detail

OBRÁZEK 6: Přepočet obvodové vůle $v$ tečné rovině do roviny normálové
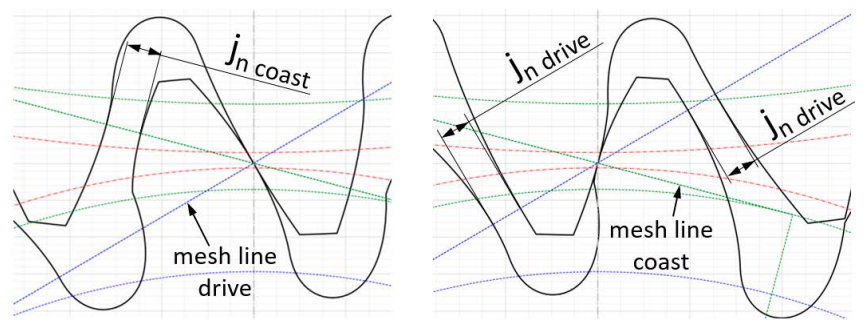

FIGURE 7: Normal backlash $j_{n}$ between coast/drive flanks while drive/ coast flanks meshing (left/right).

OBRÁZEK 7: Normálová vůle $\mathrm{j}_{\mathrm{n}}$ mezi coast/drive čely během drive/coast záběru (vlevo/vpravo).

The situation while recalculating backlashes is depicted in detail in Figure 6. This figure applies only for spur gearing, in the case of helical gearing the influence of helix angle $\beta_{w}$ cannot be depicted in transverse plane. Nevertheless, in equations (26) it is included, so computed values of $j_{n}$ shown in the program are correct.

While meshing of drive flanks, the backlash between coast flanks appears and conversely, see Figure 7. Normally the drive side is the more important one and has a higher value of mesh angle than the coast one. For this reason, backlash at the coast side is standardly also higher, see Figure 6 .

\section{APPROACH OF THIS PROGRAM, ITS APPEARANCE AND FUCTIONS}

This software was developed in the Python programming software. Units of all used and displayed values are [mm]. The KissSoft program served as an example of its appearance. One of the first versions is depicted in Figure 9. A very important difference in comparison with KissSoft lies in the approach to backlash in the gearset.

When designing a gearset, input parameters must be given. This is normally the ratio (number of teeth), working center distance and maximum addendum diameters restricted by space requirements. 


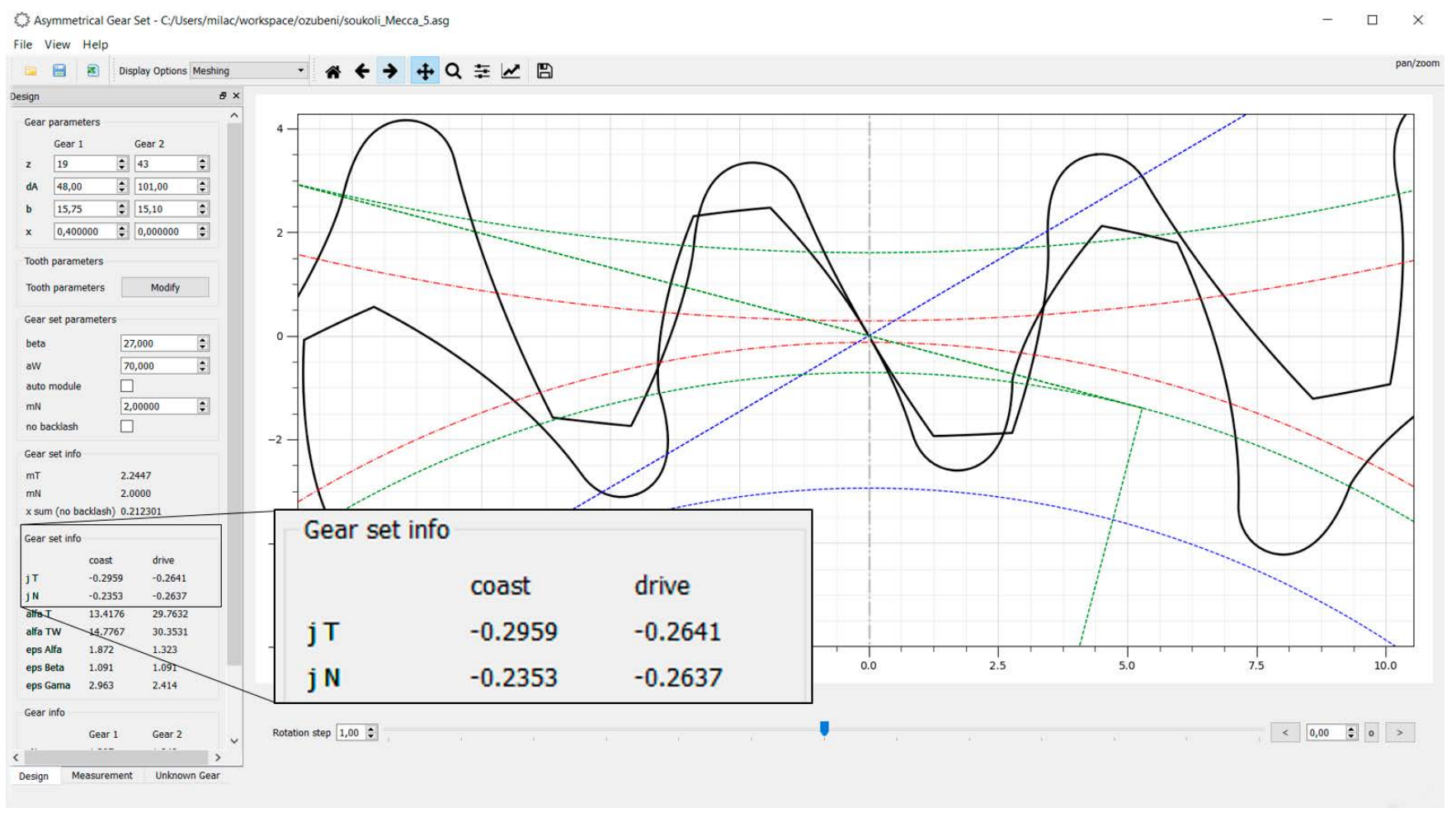

FIGURE 8: Example of the gearset with negative backlash value - nonsense OBRÁZEK 8: Příklad ozubeného soukolí se zápornou hodnotou vůle - nesmysl

Subsequently, tooth profile (mesh angle) and helix angle are determined. The result of the gearset macrogeometry design is the sum of profile shift $x_{\Sigma}$ for the condition of no backlash.

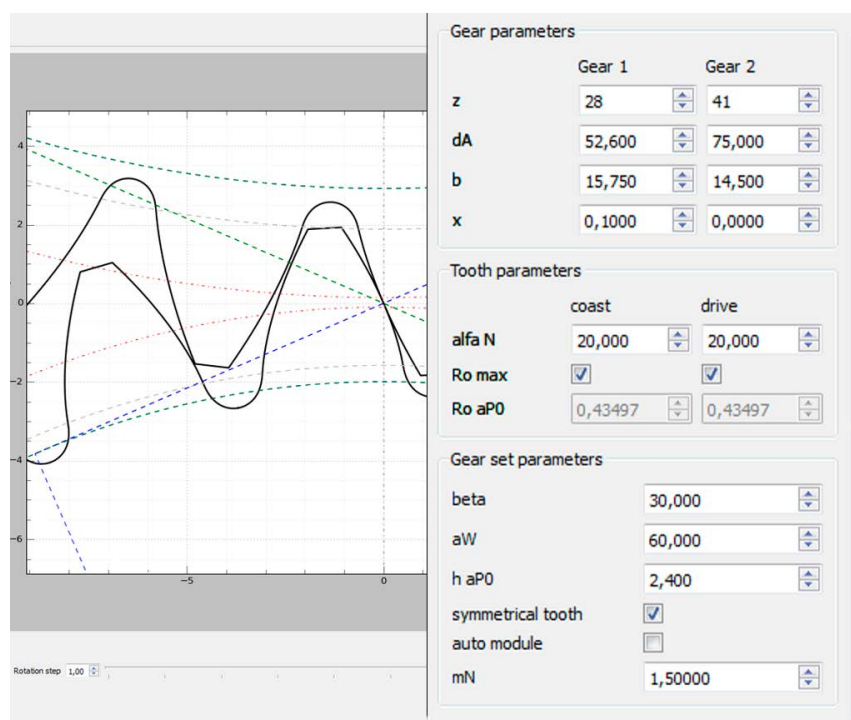

FIGURE 9: Appearance of the program initial version for depicting symmetric and asymmetric gearing - example of a gear mesh OBRÁzEK 9: Vzhled počáteční verze programu, zobrazující symetrické i asymetrické ozubení - príklad zubů v záběru soukolí
Real tooth profiles (values of $x$ - shift coefficients) are subsequently changed according to related standards (e.g. DIN 3967) to reach desired backlash, which is crucial for correct gearset function. In the case of the program described in this contribution, $x_{\Sigma}$ can be either calculated directly using formula (23) for the condition of no backlash or can be entered manually, separately for each gear including the $x$-shift coefficients. An exception to this are common parameters of both gears (e.g. helix angle). Gearwheel profiles are directly depicted including the backlash (if possible) and all needed parameters are calculated. Example of such situation is depicted in Figure 7. Indeed, the situation when negative backlash appears can occur, see Figure 8 . Of course, in reality negative backlash is nonsense, its value must be always positive. From this reason it is very important to check backlash values. Their values are enlarged in Figure 8.

Development of this software was quite demanding. In the following text its appearance and parameters at given stages are depicted and described.

The first version is depicted in Figure 9. At this stage it was possible to set only the basic parameters of the rack. These input parameters are mentioned in the following Table 1. Furthermore, for the manufacturing of both gears only one (identical) cutting tool was considered. This issue can cause the tip - root interference. Besides all necessary parameters, there is 


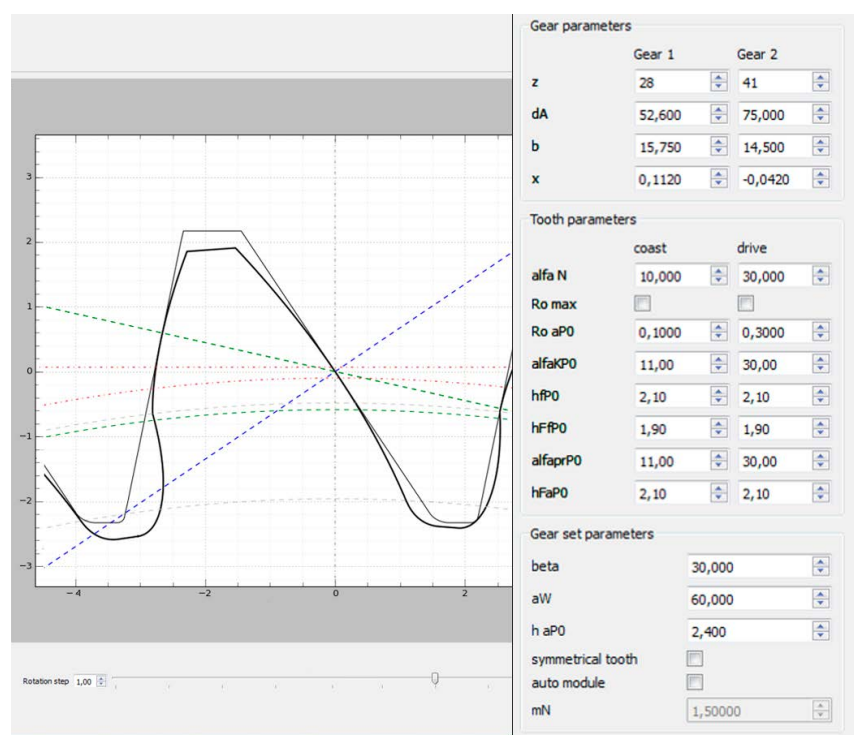

FIGURE 10: Asymmetric gear design - option "Manufacturing gear 1 ". OBRÁZEK 10: Vzhled asymetrického ozubení - možnost "Výroba kola 1". also the option of some checkboxes - for choosing of symmetricl asymmetric profile, maximum addendum rack radii at both flanks and "auto module" checkbox. This enables selection of whether the value of the normal module is calculated from other given values with no clearance (particularly the working axes distance $\left.a_{w}\right)$, or can be strictly determined. The second variant enables creation of the clearance between flanks. This function is very useful for preliminary design of the gearset. In the next steps, fine tuning of the profile can round this value to a more suitable one. In the upper-left corner it is possible to select "Display Options". Figure 13 gives an example of "Manufacturing gear 1". Figure 16 depicts the option "Meshing".

In addition to the gearing meshing, it is also very useful to see the situation while manufacturing. For this reason, there are more options for depiction - e.g. while manufacturing of both gears - meshing of the gear with the tool (rack) - depicted in Figure 10. The displayed variant can be chosen by clicking the button "Display Options" in the upper-left corner.

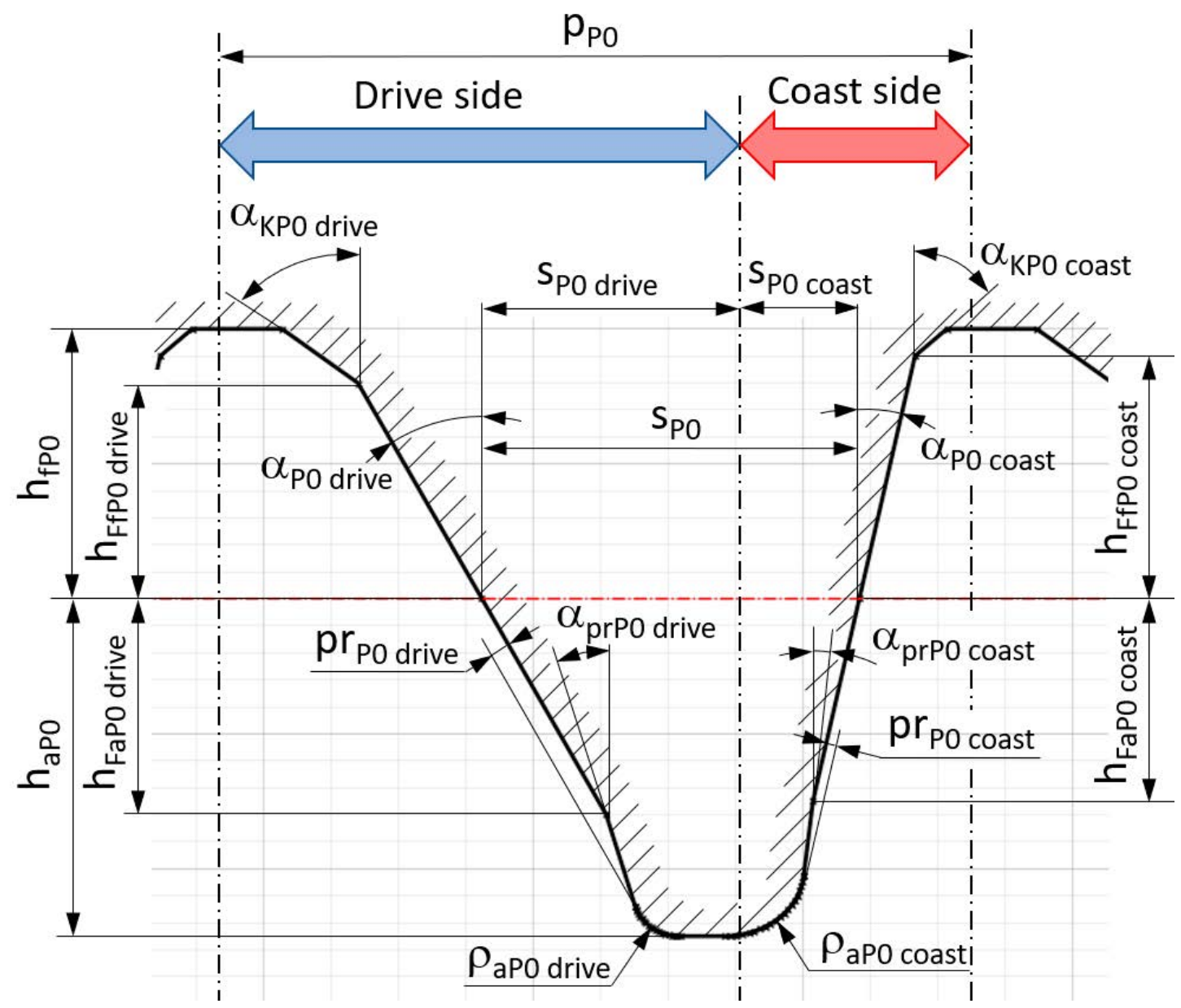

FIGURE 11: Complete appearance of manufacturing tool (rack) with asymmetric profile, tip chamfer and protuberance created by this software. OBRÁZEK 11: Kompletní vzhled výrobního nástroje (hřeben) s asymetrickým profilem, včetně sražení na hlavě a protuberance, vytvořeno popisovaným softwarem 


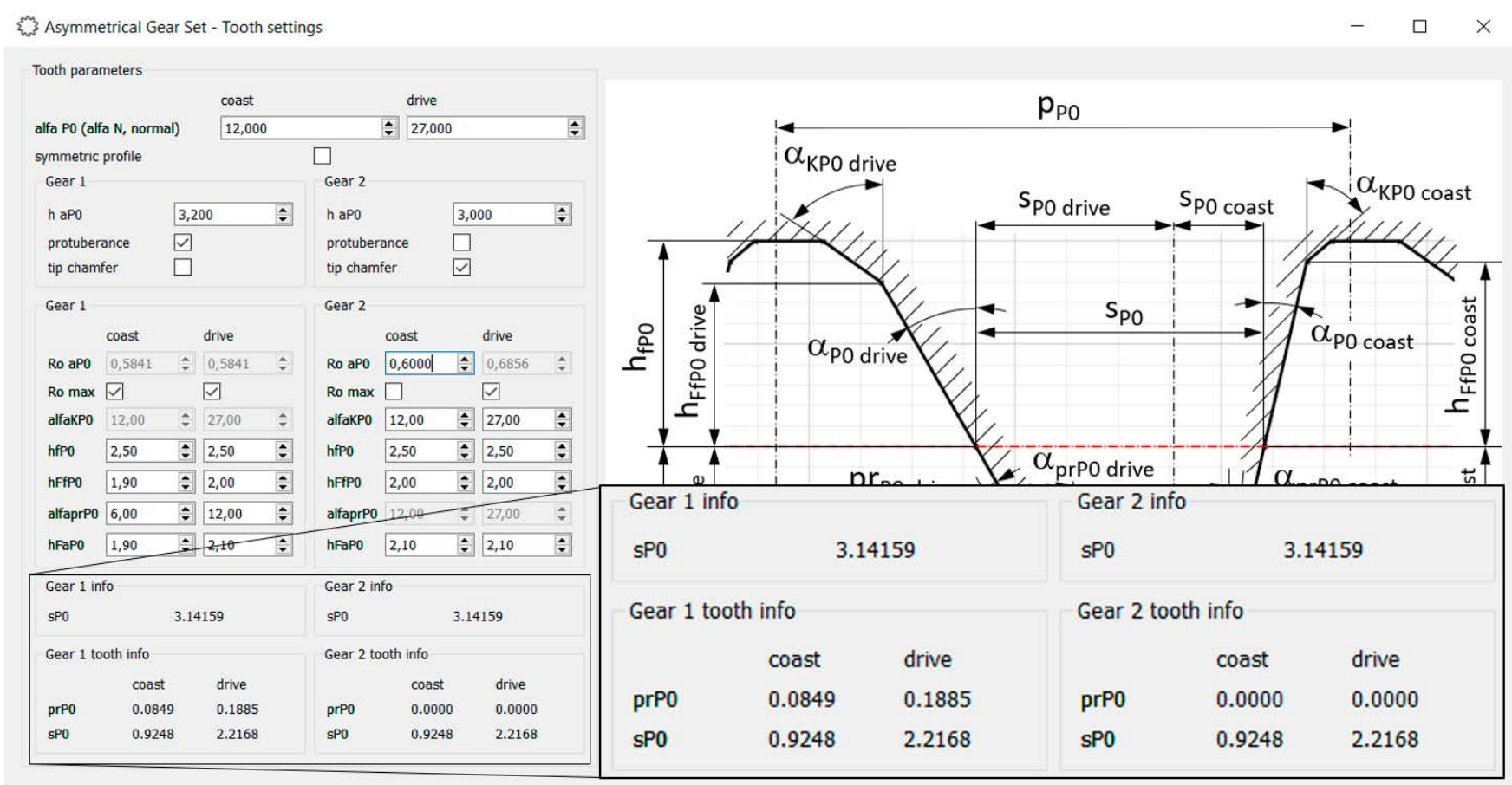

FIGURE 12: Appearance of the window for setting of a tool (rack) parameters with asymmetric profile. This window pops-up after clicking the button "Modify". OBRÁzEK 12: Vzhled okna s nastavením parametrů nástroje (hřeben) pro asymetrický profil. Toto okno se objeví po stisknutí tlačítka "Modify"

TABLE 1: Table of input parameters of the depicted gearset in Figure $9-$ for initial program version.

TABULKA 1: Tabulka vstupních parametrů soukolí, zobrazeného na Obrázku 9 - pro počáteční verzi programu.

\begin{tabular}{lcc}
\hline parameter & sign & unit \\
\hline Number of teeth & $z_{1}, z_{2}$ & - \\
\hline Normal module & $m_{n}$ & $\mathrm{~mm}$ \\
\hline Rack profile angle - drive & $\alpha_{n D}$ & $\mathrm{deg}$ \\
\hline Rack profile angle - coast & $\alpha_{n C}$ & $\mathrm{deg}$ \\
\hline Helix angle & $\beta$ & $\mathrm{deg}$ \\
\hline Facewidth & $b_{1}, b_{2}$ & $\mathrm{~mm}$ \\
\hline X- shift coefficient & $x_{1}, x_{2}$ & - \\
\hline Outer (tip) diameter & $d_{a 1}, d_{a 2}$ & $\mathrm{~mm}$ \\
\hline Axes distance & $a_{w}$ & $\mathrm{~mm}$ \\
\hline Addendum height of the rack (tool) & $h_{a P 0}$ & $\mathrm{~mm}$ \\
\hline Addendum radius of the rack (tool) - drive & $\rho_{a P 0 \_}$ & $\mathrm{mm}$ \\
\hline Addendum radius of the rack (tool) - coast & $\rho_{a P 0} C$ & $\mathrm{~mm}$ \\
\hline Number of teeth to measure over & $i$ & - \\
\hline Ball diameter to measure over & $D$ & $\mathrm{~mm}$ \\
\hline
\end{tabular}

In the version depicted in Figure 10, an improvement in the tool geometry is visible in comparison with the previous version in Figure 9. It is already possible to set a tip chamfering and a protuberance. If these options are not needed, values of appropriate profile angles $\left(\alpha_{K P 0}, \alpha_{p r P 0}\right)$ are set to same value as $\alpha_{n}$. The detailed appearance of a possible tool with tip chamfer and protuberance is depicted in Figure 11. Nevertheless, there is still only one common tool for manufacturing both gearwheels. This limitation led to an issue concerning non-equal tip - root clearance. To eliminate this issue another innovation was added to the final version. Each gearwheel has its own manufacturing tool. The only common parameters of these two tools are angles $\alpha_{P 0}$ at both sides to assure correct mesh. All other parameters can be different e.g. addendum and dedendum heights. Furthermore, the option of tip chamfering and protuberance was maintained. In total, four separate profiles of tooth flanks are defined. All these parameters can be set in a separate pop-up window after clicking the button "Modify" depicted in Figure 13. Its appearance is depicted in Figure 12.

In Figure 13 can be seen that the checkbox "no backlash" is checked. For this reason the value of $x_{\Sigma}$ was calculated and depicted in the tab "Gear set info" and furthermore, it is possible to set only the value of $x_{1}$ and the value of $x_{2}$ is computed automatically without a possibility to be changed.

All angles mentioned in this window (Figure 12) are parameters of the tool, so they are defined in the normal plane (e.g. rack profile angles $\alpha_{P 0}$ ). From all these parameters results the final tool geometry. Important tool parameters are depicted in the lower part, i.e. the protuberance magnitude ( $\mathrm{prP} 0)$ and tool 


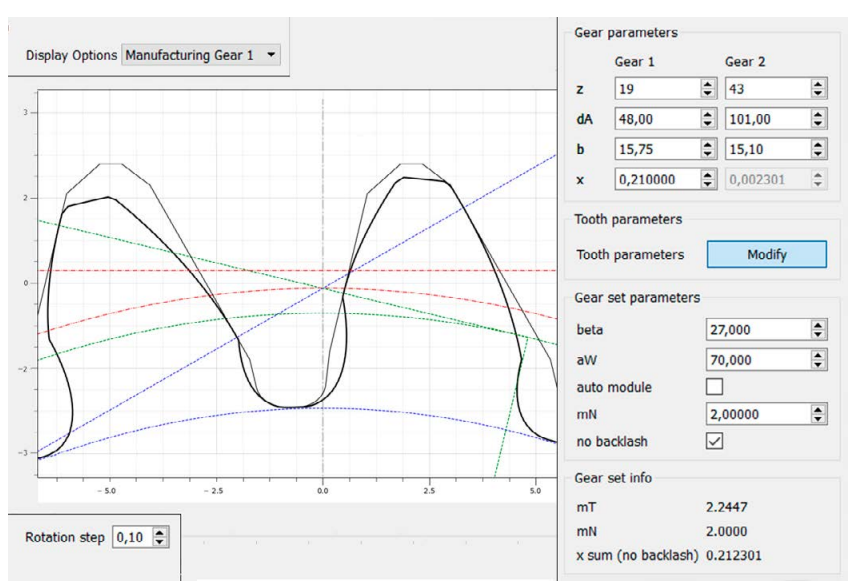

FIGURE 13: Appearance of the program including tip chamfer and protuberance - display option "Manufacturing gear 1".

OBRÁZEK 13: Vzhled programu včetně sražení na hlavně a protuberance zobrazeno nastavení "Výroba kola 1 "

thickness (sP0) at the appropriate side (flank). Furthermore, total tool thickness ( $\mathrm{sP} 0$ ) is displayed above too. The correctness of displayed values can be checked, because for the value of normal module $m_{n}=2 \mathrm{~mm}$, the value of total tool thickness $s_{P 0}$ is precisely $\pi \mathrm{mm}$. At the gear 1 protuberance was used, at the gear 2 there is no protuberance, so the value of prP0 is zero at both flanks (see Figure 12).

Regarding geometry calculations, in principle the same equations are used as for symmetric gearing. For the symmetric case it is quite simple because all computed values are divided by "2" because of the symmetry. In the case of asymmetrical gearing, all these computations are leading to a system of non-linear equations which must be solved numerically by an appropriate solver. All used equations for completing the geometry calculations were found in [1], [2], [3] and [4].

These days it is possible to use it only for external, spur and helical, symmetric and asymmetric design. All necessary parameters of the gearset can be set on the left side. In the left bottom corner are three tabs: Design, Measurement and Unknown gear, see Figure 16. In the tab "Design", basic input parameters of the gearset can be entered.

Using this program it is also possible to calculate the value of the measurement over teeth (span measurement) and over balls. This can be seen in the tab "Measurement" in the bottom-left corner. In the case of symmetric teeth both these variants are possible. In the case of asymmetric gearing, only the measurement over balls is possible because there is no common tangent between opposite involute flanks. Graphical depiction of the situation with embedded ball with the diameter " $D$ " is depicted in Figure 14 and is meaningful only for spur gearing when the depicted ball really touches both flanks. For helical gearing, the calculated value of the ball centers diameter $d_{g}$ is correct, but because of the helix angle, the inserted ball does not touch the depicted transverse gear profile.

For asymmetric profile, this ball center diameter $d_{g}$ can be computed from the system of two equations (27) and (28).
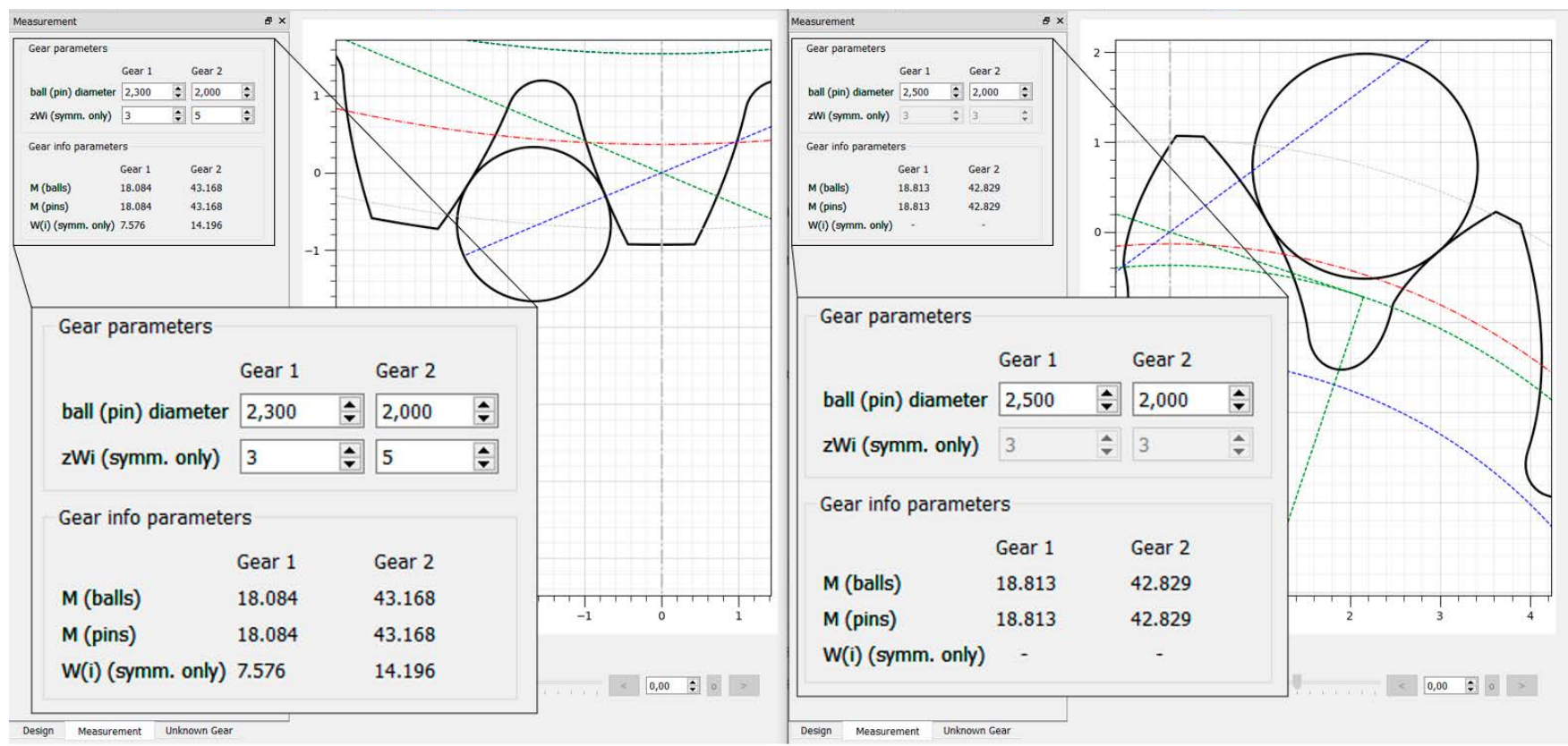

FIGURE 14: Appearance of the program tab "Measurement" for spur gearing with an symmetric (left) and asymmetric (right) profile. Embedded ball touches the transverse tooth profile.

OBRÁzEK 14: Vzhled záložky "Měření" pro přímé zubení se symetrickým (vlevo) a asymetrickým (vpravo) profilem. Měřicí kulička se dotýká tečného profilu zubu 


$$
\begin{aligned}
& i n v \alpha_{g d}+i n v \alpha_{g c}=i n v v_{d}+i n v v_{c}+ \\
& +\frac{D}{d_{b d} \cdot \cos \beta_{b d}}+\frac{D}{d_{b c} \cdot \cos \beta_{b c}}-\frac{2 \cdot \pi}{Z} \\
& \left(d_{g}=\right) \frac{d_{b d}}{\cos \alpha_{g d}}=\frac{d_{b c}}{\cos \alpha_{g c}}
\end{aligned}
$$

Used angles inv $v_{d}$ and inv $v_{C}$ in the formula (27) can be computed using formulas (29).

$$
i n v v_{d}=\frac{s_{t d}}{r}+i n v \alpha_{t d}, \quad i n v v_{c}=\frac{s_{t c}}{r}+i n v \alpha_{t c}
$$

The angular position of embedded ball related to the tooth axis is for symmetric profile given quite easily as half of the angle related to the one tooth pitch, see formula (30).

$\varepsilon_{\text {ball, } \mathrm{symm}}=\frac{2 \cdot \pi}{2 \cdot z}=\frac{\pi}{Z}$

In case of asymmetric profile, this angle $\varepsilon_{\text {ball }}$ can be derived from the Figure 15. If the diameter $d_{g}$ is already known, we can focus only on the drive side, where the "touching" angle $\alpha_{t T d}$ is

$\alpha_{t T d}=\operatorname{arctg}\left(\operatorname{tg} \alpha_{g d}-\frac{D}{d_{b d}}\right)$

The radius of the touching point can be computed thanks to contact angle $\alpha_{t T d}$ as

$r_{T d}=\frac{r_{b d}}{\cos \alpha_{t d}}$

Tooth thickness of the drive side at this radius $s_{t T d}$ can be subsequently computed

$s_{t T d}=r_{T d} \cdot\left(\frac{s_{t d}}{r}+i n v \alpha_{t d}-i n v \alpha_{t T d}\right)$

To this thickness $s_{t T d}$ relates at a radius $r_{T d}$ an appropriate angle $\mathcal{E}_{t T d}$

$\varepsilon_{t T d}=\frac{s_{t T d}}{r_{T d}}$
And finally, the desired angle between the tooth axis and embedded ball $\varepsilon_{\text {ball }}$ is

$\varepsilon_{b a l l}=\varepsilon_{t T d}+\alpha_{g d}-\alpha_{t T d}$

The final formula for the measurement over balls " $M$ " is then for even number of teeth

$$
M=d_{g}+D
$$

and for the gearwheels with odd number of teeth same recalculation formula as for standard symmetric profile holds true, see equation (37).

$$
M=d_{g} \cdot \cos \frac{\pi}{2 \cdot z}+D
$$

The tab "Unknown Gear" enables identification of unknown gear parameters using measured normal thickness at a given depth. The measured unknown gear profile can then be visually compared with the gear profile designed in the tab "Design". If both these depicted profiles match, then parameters of the unknown gear are set. This method can only be used for spur symmetric gearing and is very inaccurate.

For gearset optimizing from the perspective of qualitative properties, all necessary values are computed and depicted in the part "Gear set info" e.g. normal and tangential backlash $\left(j_{n}\right.$ - drive/coast), transverse contact ratio $\left(\varepsilon_{\alpha}\right.$ - drive/coast), axial contact ratio $\left(\varepsilon_{\beta}-\right.$ drive/coast), total contact ratio $\left(\varepsilon_{\chi}\right.$ - drive/ coast), minimum tip thickness without chamfering $\left(s_{n a}\right)$ and minimum tip - root clearance $\left(c_{a}{ }^{*}[-]\right)$, see Figure 16.

Coordinates of tooth flank points, which are calculated analytically, don't have the same distance between each other. To

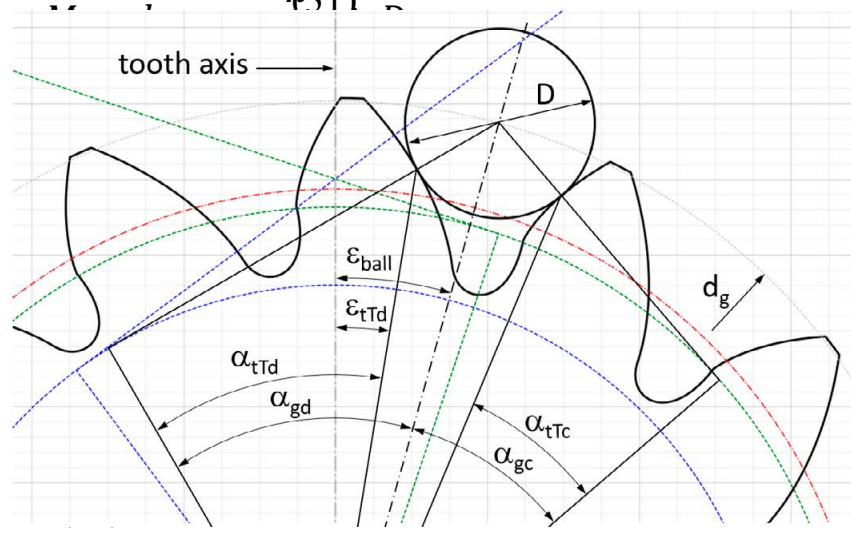

FIGURE 15: Geometry of the measurement over balls for the asymmetric profile OBRÁZEK 15: Geometrie měření přes kuličky, asymetrický profil 


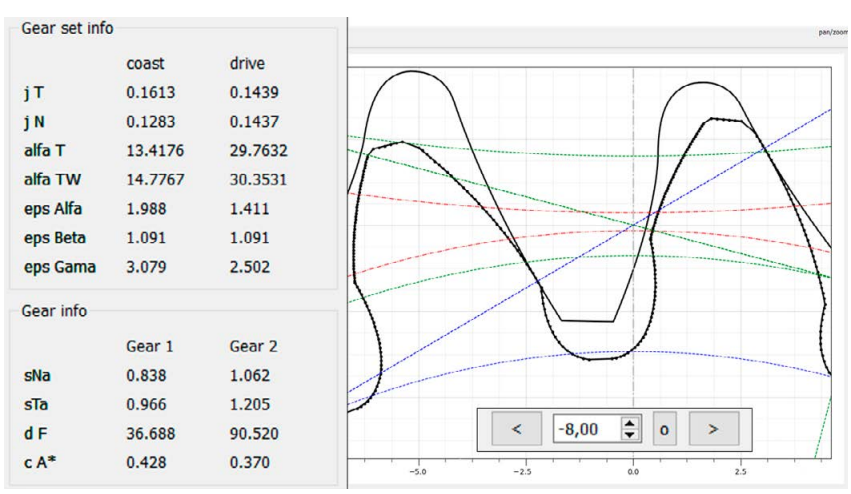

FIGURE 16: Appearance of the program including tip chamfer and protuberance - display option "Meshing". Gear 1 is depicted using interpolating spline with highlighted equidistant points.

OBRÁZEK 16: Vzhled programu, včetně sražení hlavy a protuberance možnost nastavení "Soukolí." Kolo 1 je zobrazeno s pomocí interpolační křivky se zvýrazněnými ekvidistantními body

assure correct depicting, these calculated points are interpolated using spline curves, whose intersections are subsequently computed. This approach is applied for both intersections, i.e. for tip chamfer involute $\left(\alpha_{K P 0}\right)$ and active involute $\left(\alpha_{P 0}\right)$, and for active involute $\left(\alpha_{P 0}\right)$ and tooth root fillet curve. Then these splines are defined by a given number of equidistant points. In some special cases there can occur a situation where active involute $\left(\alpha_{P 0}\right)$ is shortened (cut) by an involute created by linear part of tool protuberance $\left(\alpha_{\text {prpo }}\right)$. Firstly, to find this intersection is numerically very problematic (unstable) and secondly, the magnitude of this phenomenon is very small. For these reasons, this whole part of the tooth flank is neglected in this software. These equidistant points of the tooth profile are depicted for gear 1 in Figure 16.

The final interesting property of this program can be found in a very useful function - "kinematics". It is possible to change the angular position of the gearset, so the whole "passing through the mesh" of a gear pair or the gearwheel - rack meshing, can be observed. It can be done with arrows in the bottom-right corner, see Figure 16. To be able to set a precise gear mesh position, it is possible to set the magnitude of rotational step (bottomleft corner of Figure 13) and absolute angular position of the gearset (bottom-right corner of the Figure 16). This function is very illustrative for students during lessons. Furthermore, tip root interference can be visually detected while rotating the gearset. Finally, it must also be mentioned that no commonly used deviations of all important dimensions (e.g. backlash magnitude $j_{n}$ or working center distance $a_{w}$ ) are included in the finally designed profile. Both these gear profiles are purely theoretical. To be able to determine desired values (e.g. normal backlash $j_{n}$ ) including their tolerances, all input values must be set to their both tolerance extremes (maximum and minimum value in the appropriate tolerance range).

\section{CONCLUSION}

This contribution briefly described external involute gearing with asymmetric profile, its advantages, disadvantages and, above all, the program for its design - its previous and final appearance and functions. The formula for the sum of profile $x$-shift coefficient for the case of no backlash was derived. Furthermore, there was described a special property of this program regarding to displaying the gearset with a backlash due to the possibility of setting arbitrary values of the $x$-shift profile coefficients. All necessary basic equations were mentioned.

\section{ACKNOWLEDGEMENTS}

This research has been realized using the support of The Technology Agency of the Czech Republic, programe National Competence Centres, project \# TN01000026 Josef Bozek National Center of Competence for Surface Transport Vehicles. This support is gratefully acknowledged.

\section{REFERENCES}

[1] MORAVEC, Vladimír. Konstrukce strojů a zařízení II: čelní ozubená kola. Ostrava: Montanex, 2001. ISBN 80-7225-051-5.

[2] KAPELEVICH, Alexander L. Direct gear design. Boca Raton: CRC Press, Taylor \& Francis Group, 2013. ISBN 978-1-4398-7618-3.

[3] NĚMČEK, Miloš. Vybrané problémy geometrie čelních ozubených kol. Ostrava: Montanex, 2003. ISBN 978-80-7225-111-7.

[4] ŠALAMOUN, Čestmír a M SUCHÝ. Čelní a šroubová soukolí s evolventním ozubením. Praha: Nakladatelství technické literatury, 1990. ISBN 978-80-03-00532-1. 